\title{
Short-term impacts of energy wood harvesting on ectomycorrhizal fungal communities of Norway spruce saplings
}

\author{
Karoliina Huusko ${ }^{1}$, Oili Tarvainen ${ }^{2}$, Karita Saravesi ${ }^{1}$, Taina Pennanen ${ }^{3}$, Hannu Fritze ${ }^{3}$, \\ Eero Kubin ${ }^{2}$ and Annamari Markkola ${ }^{1}$ \\ ${ }^{1}$ Department of Biology, University of Oulu, Oulu, Finland; ${ }^{2}$ Oulu Unit, Finnish Forest Research Institute, \\ Oulu, Finland and ${ }^{3}$ Vantaa Unit, Finnish Forest Research Institute, Vantaa, Finland
}

\begin{abstract}
The increased demand for harvesting energy wood raises questions about its effects on the functioning of the forest ecosystems, soil processes and biodiversity. Impacts of tree stump removal on ectomycorrhizal fungal (EMF) communities of Norway spruce saplings were studied with 454-pyrosequencing in a 3-year field experiment replicated in 3 geographical areas. This is possibly the most thorough investigation of EMF communities associated with saplings grown on sites subjected to energy wood harvesting. To separate impacts of tree stump and logging residue removal on EMF and plant variables, we used three harvesting treatments with increasing complexity from patch mounding alone $(P)$ to patch mounding combined with logging residue removal (RP), and patch mounding combined with both logging residue and stump removal (SRP). Saplings grown in uncut forests (F) served as references for harvesting treatments. A majority of sequences ( $>92 \%)$ and operational taxonomic units (OTUs, $55 \%$ ) were assigned as EMF. EMF OTU richness, fungal community composition or sapling growth did not differ between harvesting treatments ( $P$, RP and SRP), while EMF OTU richness, diversity and evenness were highest and sapling growth lowest in the undisturbed reference forests (F). The short study period may partially explain the similarities in fungal and sapling variables in different harvesting treatments. In conclusion, our results indicate that neither stump removal nor logging residue removal have significant additional negative impacts on EMF communities or growth of Norway spruce saplings in the short-term compared with the impacts of more conventional harvesting methods, including clear cutting and patch mounding.
\end{abstract}

The ISME Journal (2015) 9, 581-591; doi:10.1038/ismej.2014.154; published online 29 August 2014

\section{Introduction}

In recent years, the practice of energy wood harvesting has rapidly increased due to economic and environmental considerations. The European Union has agreed to reduce greenhouse gas emissions and increase the overall share of renewable energy production by $20 \%$ by the year 2020 (EU, 2009). National targets for biofuel production, for example, in Finland and Sweden, are set as high as 38\% and $49 \%$, respectively (EU, 2009). The growing market for wood fuel has led to a rapid increase in the use of logging residue (that is, branches and foliage), and more recently also that of tree stumps and roots (Björheden, 2006; Díaz-Yáñez et al., 2013). However, combined impacts of residue and stump harvesting, especially on soil processes and biota, are still poorly understood. Compared with stem harvest only, collecting also stumps and logging residues

Correspondence: K Huusko, Department of Biology, University of Oulu, P.O. Box 3000, Oulu FI-90014, Finland.

E-mail: maija.huusko@oulu.fi

Received 9 January 2014; revised 17 June 2014; accepted 17 July 2014; published online 29 August 2014 intensifies the loss of both soil nutrient and carbon (C) stocks (Palviainen et al., 2010; Walmsley and Godbold, 2010), which may have cascading effects on soil microbiota and further on the new regenerating tree cohort.

Most boreal forest trees form an association with ectomycorrhizal fungi (EMF) in their roots. Nutrient and water availability of trees is greatly improved by EMF symbionts, whereas EMF gain photosynthetic $\mathrm{C}$ from trees (Smith and Read, 2008). EMF have an essential role in forest functioning, as they fuel the soil subsystem with recently fixed C (Godbold et al., 2006; Clemmensen et al., 2013). In addition, many EMF are capable of enzymatic uptake of organic nitrogen (N). This is crucial, as $\mathrm{N}$ is considered to be the most limiting nutrient in boreal forests. Despite the large stock of organically bound $\mathrm{N}$ in forest soil, organic $\mathrm{N}$ is otherwise mainly inaccessible for trees (Lindahl et al., 2007; Read and Perez-Moreno, 2003). Besides enzymatic uptake, EMF may specialize in nutrient mobilization over long distances (Agerer, 2001). Thus, maintaining high EMF diversity in roots has been shown to have an impact on the host tree productivity in the field (Korkama et al., 2006; 
Saravesi et al., 2011). In more controlled laboratory conditions, tree seedling growth increased with higher number of EMF associated with their roots, but the effect was dependent on tree species and nutrient status in the soil (Jonsson et al., 2001), as well as on functional complementarity of the EMF community (Velmala et al., 2014).

Silvicultural practices such as clear cutting and site preparation have a significant impact on EMF communities of establishing seedlings. However, remaining tree stumps and roots may retain EMF fungi for some years after their host trees have been harvested (Hagerman et al., 1999; Heinonsalo and Sen, 2007; Heinonsalo et al., 2007). The time scale for turnover of mycorrhizal roots, sclerotia and hyphae, as well as preservation of fungal inoculum potential in roots and soil may vary depending on fungal species (Jones et al., 2003). Compared with the substantial impacts of clear cutting on soil microbiota, collecting aboveground logging residues seems to have a lesser impact, as no significant longterm effects have been reported either on EMF or saprotrophic fungal communities (Mahmood et al., 1999; Allmér et al., 2009). On the other hand, reports on the effects of stump harvesting on EMF are scarce and partially contradictory. Stump removal decreased the number of EMF morphotypes in Douglas fir roots with a simultaneous reduction in growth and $\mathrm{N}$ content of seedlings (PageDumroese et al., 1998). In contrast, stump removal increased Norway spruce seedling growth, but had either no effect on EMF morphotypes (Kataja-aho et al., 2012) or reduced EMF richness in roots (Menkis et al., 2010). Hence, impacts of stump removal and collecting logging residues on belowground microbial communities, especially on EMF, require further studies.

Our aim was to estimate how energy woodharvesting practices contribute to EMF communities and growth of Norway spruce (Picea abies (L). Karst) saplings, on a south-to-north geographical gradient spanning from the southern boreal to middle boreal vegetation zones. The focus was on possible changes in root fungal diversity and community composition due to altered inoculum potential of disturbed forest soil, and further, on potential impacts on sapling growth. We expected differences in EMF along an increasing complexity of energy wood-harvesting practices, including patch mounding, logging residue removal and stump removal. Further, we expected stump removal to decrease EMF inoculum potential, possibly resulting in lower EMF diversity and, consequently, reduced sapling growth compared with other harvesting treatments.

\section{Material and methods}

Study areas and experimental layout

Spruce-dominated forest stands were chosen in South $\left(60^{\circ} 48^{\prime} \mathrm{N}, 26^{\circ} 55^{\prime} \mathrm{E}\right)$, Central $\left(61^{\circ} 40^{\prime} \mathrm{N}, 24^{\circ} 48^{\prime} \mathrm{E}\right)$ and North $\left(64^{\circ} 27^{\prime} \mathrm{N}, 27^{\circ} 33^{\prime} \mathrm{E}\right)$ Finland. The two southern areas belong to the southern boreal vegetation zone and the most northern area to the middle boreal vegetation zone (Ahti et al., 1968). Stand properties (for example, age, density and height) and climatic factors varied depending on the area (Table 1).

Within each study area, three replicate blocks consisting of four experimental plots of $c a$. $40 \mathrm{~m} \times 40 \mathrm{~m}$ were established. The blocks of $0.5-1$ ha were located at a distance ranging from $0.2-15 \mathrm{~km}$ from each other. One of four plots was the uncut reference plot (reference forest, F). The other three were experimental clear-cut plots with different harvesting treatments increasing in complexity from (1) patch mounding alone (P) to (2) patch mounding with $70 \%$ of logging residue removal (RP) and (3) patch mounding combined with both $70 \%$ of logging residue removal and partial stump removal (SRP) with 25 stumps left per hectare. The total number of experimental plots was 36 (that is, 3 geographical areas $\times 3$ replicate blocks $\times 4$ treatment plots).

Trees were felled from all experimental plots during winter 2007/2008 and delimbed at the plots. Logging residues (branches with needles) were collected with a bundler and stumps were dug out of the ground with an excavator in June 2008 according to harvesting treatments and left at the plots for 6 weeks to dry before removing. In the harvesting treatment $\mathrm{P}$, where logging residues were not collected, residues were spread evenly on plots. In August 2008, 1.5-year-old nursery-grown Norway spruce seedlings were planted on four mounds (height $0.2 \mathrm{~m}, \sim 0.6 \mathrm{~m}^{2}$ in size) located in different quadrants of each harvesting treatment plot and in a similar fashion on intact forest floor in reference forest plots at all experimental areas. The distance between planting mounds was $10-20 \mathrm{~m}$. Seedlings of local origin were used for each geographical study area. Peat containerized seedlings planted in the South and Central areas were grown in a nursery in Joroinen, and those planted in the North area, in Tuusniemi. Conifer seedlings in nurseries

Table 1 Climatic, stand structure and soil characteristics for three studied areas in Finland

\begin{tabular}{lccc}
\hline & Anjalankoski & Längelmäki & Paltamo \\
\hline Area abbreviation & South & Central & North \\
Elevation (m asl) & $65-79$ & $117-158$ & $206-214$ \\
Annual air temperature $\left({ }^{\circ} \mathrm{C}\right)^{\mathrm{a}}$ & 5.3 & 4.6 & 2.5 \\
Annual precipitation $(\mathrm{mm})^{\mathrm{a}}$ & 716 & 658 & 690 \\
${\text { Temperature sum }\left(>5{ }^{\circ} \mathrm{C}\right)^{\mathrm{a}}}$ & 1539 & 1367 & 1113 \\
& & & \\
${\text { Picea/Pinus/Betula }(\%)^{\mathrm{b}}}$ & $77 / 20 / 2.4$ & $89 / 0.8 / 6.6$ & $96 / 1 / 1.7$ \\
Stand age in 2007 (years) $^{\mathrm{c}}$ & 90 & 79 & 158 \\
Soil texture $^{\mathrm{d}}$ & Loamy sand & Sandy loam & Sandy loam
\end{tabular}

aAverage for years 2007-2011 (Venäläinen et al., 2005).

bPoportion of Picea abies, Pinus sylvestris and Betula spp. from all trees.

${ }^{\mathrm{c}}$ Measured from 54 Picea abies trees in each area separately.

${ }^{\mathrm{d}}$ According to USDA classification (Soil Survey Staff, 1999). 
commonly possess a typical combination of EMF, including Thelephora, Amphinema, Laccaria and Cenococcum spp. (Hunt, 1992; Kernaghan et al., 2003; Flykt et al., 2008) adapted to high-fertility conditions applied at nurseries. Seedlings planted at our South and Central study areas were grown in the same nursery as those in Kataja-aho et al. (2012), with a high and consistent EMF colonization (96\%) dominated by Thelephora terrestris $(74.4 \%)$.

\section{Sampling and sample preparation}

After three full growing seasons, spruce saplings were harvested in September 2011. One sapling from each experimental mound in a plot was dug up with its intact root system and was packed into a 20-l plastic bag. This resulted in a total of 142 harvested saplings (2 saplings were missing). Intact saplings were kept in $6{ }^{\circ} \mathrm{C}$ until preparation (3 weeks at maximum). The main shoot was cut off, current year shoot height growth measured and shoot dry weight determined after drying for $48 \mathrm{~h}$ at $40{ }^{\circ} \mathrm{C}$. The root system was manually separated from soil and prewashed in a container filled with tap water using an orbital shaker. After shaking, the root system was placed on a sieve and washing was continued under running tap water. Root samples were collected systematically around the whole sapling root system (altogether 8-10 root fragments of $10-15 \mathrm{~cm}$ in length and $<5 \mathrm{~mm}$ in diameter). For saplings grown in reference forest $(\mathrm{F})$ plots, the root fragment length was shorter $(\sim 5-10 \mathrm{~cm})$. Root samples were further cleaned under a stereomicroscope using forceps and a random subset of fine roots $(<1 \mathrm{~mm})$ was collected and stored at $-20{ }^{\circ} \mathrm{C}$. Fine roots were freeze dried for $24 \mathrm{~h}$ in $-48{ }^{\circ} \mathrm{C}$ and their dry weight (ranging from 50-170 mg) was determined before DNA extraction.

\section{Soil nutrient analyses}

Soil from the sapling rhizosphere was collected after gently shaking the root system (on average $15-20 \mathrm{~cm}$ of radius and $20 \mathrm{~cm}$ of depth). Four random samples of $c a .15 \mathrm{ml}$ were taken with spoon from the surface of rhizosphere soil of each sapling, combined and stored at $-20^{\circ} \mathrm{C}$ until analyzed. In harvesting treatments (P, RP and SRP) the samples consisted mostly of mineral soil from mounds, and in the reference forest $(\mathrm{F})$ the samples included soil from both organic and mineral soil layers. All rhizosphere soil samples (3-4 samples, $8.8 \pm 0.32 \mathrm{~g}$ each) from the same plot were pooled by mixing and removing rocks, litter and root parts, and then homogenizing samples in a container. Moisture content $\left(105^{\circ} \mathrm{C}\right.$, $20 \mathrm{~h})$ and organic matter $\left(500^{\circ} \mathrm{C}, 4 \mathrm{~h}\right)$ of the soil samples were determined. Soil subsamples $(2.9 \pm 0.16 \mathrm{~g})$ were dried at $60^{\circ} \mathrm{C}$ before nutrient analyses. Total nitrogen (N) concentration was analyzed by a modified Kjeldahl method and phosphorus by a modified molybdenum blue method, using the standard methods of the Finnish Forest Research Institute, described in Supplementary Information S1.

DNA extraction, PCR amplification and sequencing Freeze-dried root samples were homogenized in liquid nitrogen in a mortar. Samples from four saplings from the same plot were pooled by taking $35-40 \mathrm{mg}$ dry weight of each homogenized root sample resulting in 36 samples (140-160 mg dry weight) for DNA extraction. Before DNA extraction, pooled samples were freeze dried for $2.5 \mathrm{~h}$ again. Total DNA was extracted from $20 \mathrm{mg}$ of root powder with the PowerSoil DNA isolation kit (MoBio, Carlsbad, CA, USA) following the manufacturer's instructions, with the exception that DNA was eluted in $50 \mu \mathrm{l}$ of the elution buffer C6. All templates were quantified with a Nano-Drop ND1000 UV-vis Spectrophotometer (Thermo Scientific, Wilmington, DE, USA) and adjusted to a final

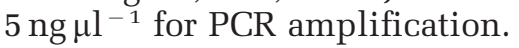

Samples were prepared for 454-pyrosequencing by amplifying the ITS2 region of rDNA with fungalspecific primers ITS4 and 58A2F (White et al., 1990; Martin and Rygiewicz, 2005). Fusion primers were constructed by adding the 454-pyrosequencing adapter $\mathrm{A}$ and a 10-bp unique tag in ITS4 and adapter B in 58A2F (Marguelis et al., 2005).

Fungal ITS2 was amplified in $20 \mu \mathrm{l}$ volumes in three separate PCR reactions to account for potentially heterogeneous amplification from the root template. Each reaction contained reagents as follows: $0.2 \mu \mathrm{M}$ of each primer, $10 \mathrm{ng}$ of the template DNA, $125 \mu \mathrm{M}$ of each deoxynucleotide triphospate, $4 \mu \mathrm{l} 5 \times$ Phusion HF buffer and $0.2 \mu$ l High Fidelity Phusion DNA Polymerase (Thermo Fisher Scientific Inc., Waltham, MA, USA). PCR cycle parameters consisted of an initial denaturation at $95^{\circ} \mathrm{C}$ for $3 \mathrm{~min}$, then 27 cycles of denaturation at $95^{\circ} \mathrm{C}$ for $15 \mathrm{~s}$, annealing at $50{ }^{\circ} \mathrm{C}$ for $20 \mathrm{~s}$ and extension at $72{ }^{\circ} \mathrm{C}$ for $1 \mathrm{~min}$, followed by a final extension step at $72{ }^{\circ} \mathrm{C}$ for $7 \mathrm{~min}$. All PCR reactions were performed on MasterCyclers (Eppendorf, Hamburg, Germany). Fresh PCR products were visualized on $1.5 \%$ gels with Midori Green DNA stain (Nippon Genetics Europe Gmbh, Düren, Germany).

Replicate amplicons $(15 \mu \mathrm{l})$ for each sample were purified with Ampure XP (Beckmann-Coulter, Beverly, MA, USA) and pooled in equimolar quantities. The pooled sample was further size-selected with $1.5 \%$ agarose gel, excised DNA was eluted from a gel slice with the Minelute Kit (Qiagen, Germantown, MD, USA). Finally, the sample was purified with Ampure XP and pyrosequenced with 454 Roche GS Junior at BioSer Oulu, University of Oulu, Finland.

Bioinformatics and taxonomic assignment

We used QIIME 1.5.0. software to control the quality of sequences (Caporaso et al., 2010), described in 
detailed in Supplementary Information S2. Lowquality sequences were filtered out, and ambiguous bases, primer mismatches, homopolymers $<6 \mathrm{bp}$ and sequences with length $<150 \mathrm{bp}$ or $>500 \mathrm{bp}$ were removed. Sequencing noise was removed by flowgram clustering with Denoiser (Reeder and Knight, 2010). After inflating Denoiser results, sequences were clustered at default $97 \%$ similarity using the UCLUST algorithm (Edgar, 2010) in QIIME with the optimal flag option, after which representative sequences for operational taxonomic units (OTUs) were selected.

For fungal identification to the most accurate taxonomic level, the representative sequences were aligned in GenBank and UNITE (Abarenkov et al., 2010) databases using the BLAST tool (MegaBlast). BLAST results were examined carefully, especially the graphical overview and pairwise alignments, to detect anomalies and chimeras. Global singletons, chimeras, representative sequences $<180 \mathrm{bp}$, query coverage $<80 \%$ or hit $<97 \%$, and non-fungal OTUs were excluded from further analyses. Taxonomic assignments for fungal OTUs were given manually based on BLAST hits and functional roles (ectomycorrhizal, other mycorrhizal, saprophytic, other and unknown; Rinaldi et al., 2008; Tedersoo et al., 2010) were determined. Representative sequences of fungal OTUs, including those with a length of $>200 \mathrm{bp}$ and the 25 most common OTUs, have been submitted to GenBank database under accession numbers KJ008713-KJ008913.

\section{Data analyses}

All statistical analyses were carried out using $\mathrm{R}$ 2.15.3 (R Development Core Team, 2013). The sequence number per sample varied between 1104 and 2757. Sequence data was rarefied to the lowest sequence number (1104) using 1000 iterations with the function rrarefy from the vegan package (Oksanen et al., 2013). Frequencies of total OTUs and OTUs belonging to different functional groups were counted for each sample. Diversity indices (Shannon's H', inverse Simpson's D) were calculated with the vegan package (Oksanen et al., 2013).

Differences in fungal OTU, sapling and soil parameters were analyzed using linear mixed models (Bates et al., 2011). In order to explore the effects of treatments, we used 'treatment' (SRP, RP, P and F) as a fixed factor and 'geographical area' (South, Central and North) and 'block within area' were used as random factors. For differences between the geographical areas within each treatment, we used 'area' as a fixed factor and 'block' was used as a random factor. Count data were analyzed using a generalized linear mixed model (glmer, Laplace approximation) with Poisson error distribution, and continuous data by a linear mixed model (lmer, restricted maximum likelihood) with Gaussian error distribution. Arcsine square root transformation was used for proportion data (Crawley, 2007). Normality and homogeneity of model residuals were checked using residual diagnostic plots. The estimated difference between two means was considered as statistically significant $(P<0.05)$, when the absolute value of $t$ - or $z$-score in mixed models was $\geqslant 2$ (Crawley, 2007). The $t$ - and $z$-scores were obtained by dividing the model parameter estimates (coefficients) with model s.e.

Fungal OTU assemblages of sapling roots were visualized using non-metric multidimensional scaling (NMDS) and compared using permutational multivariate analysis of variance in the vegan package (adonis, Oksanen et al., 2013). 454-Pyrosequencing is a semi-quantitative method, as the sequence count of an OTU does not always match with the biological abundance (DNA) of that OTU in a sample (Amend et al., 2010). Therefore, NMDS ordinations and tests were done primarily based on the presence-absence data and Jaccard indices. We also tested data without reference forest plots in order to solely compare harvesting treatments. In addition, differences in fungal OTU community compositions between geographical areas were tested. Subsequently, we fitted plot- and saplingrelated variables (Supplementary Table S3) to NMDS ordination to explore the relative importance of these variables in structuring EMF communities. We used the function envfit from the vegan package (Oksanen et al., 2013) to identify variables that were significantly correlated with community composition of EMF. The significance of correlations was assessed by comparing the $r^{2}$-fit to $r^{2}$-values generated via 999 random permutations of these variables. Vectors with a correlation $r>0.69$ and $P<0.01$ were considered as significantly correlating with community data.

We examined the relationships between fungal OTUs and different treatments by indicator species analysis with the indicspecies package (De Cáceres and Legendre, 2009). Indicator OTUs (indicator value $>0.7, P<0.05)$ were detected for each harvesting treatment (P, RP and SRP) and reference forest (F) separately. Moreover, indicators for more than one treatment were detected.

\section{Results}

\section{Fungal communities in sapling roots}

The number of raw sequences in the GS Junior 454 run was 65382 . After quality control, the data consisted of 58615 sequences, and after rarefaction 39744 , representing 207 OTUs. Of all OTUs, 113 were functionally assigned as ectomycorrhizal (EMF), 10 as other mycorrhizal, 25 as saprophytic and the rest as other or unknown fungal functional groups. EMF covered the majority of OTUs in all plots (Table 2) and $>92 \%$ of all sequences in the whole data.

Harvesting treatments had parallel impacts on fungal communities of Norway spruce sapling roots. 
The combination of stump and residue removal with patch mounding (SRP) did not differ significantly in its impacts on overall fungal OTU community composition (Figure 1, Table 3a and Supplementary Table S4a), OTU richness or diversity indices (Table 2) from those of patch mounding (P) alone or combined with logging residue removal (RP). However, comparing reference forests (F) with harvesting treatments (SRP, RP and P) revealed that in uncut reference forest fungal OTU communities in sapling roots were different (Table $3 b$ and Supplementary Table S4b) with higher evenness and lower dominance (Table 2) than those in harvesting treatments.

Furthermore, fungal OTU assemblages differed between geographical areas (South, Central and North) (Tables 3a,b and Figure 1), most clearly so, within reference forests (permutational multivariate analysis of variance: $\mathrm{F}_{2,6}=1.455, R^{2}=0.327$ $P<0.01)$. However, there were no differences in

Table 2 Means of total root fungal OTUs, diversity indices (Shannon H' and Inverse Simpson D) and richness in different functional groups (EMF, other mycorrhizal, saprophytic, other, unknown) in different harvesting treatments (SRP, RP, P) and F, and in different areas (South, Central, North)

\begin{tabular}{|c|c|c|c|c|c|c|c|c|}
\hline & \multicolumn{3}{|c|}{ Diversity } & \multicolumn{5}{|c|}{ Richness of functional groups } \\
\hline & $\begin{array}{l}\text { Total OTU } \\
\text { number }\end{array}$ & $\begin{array}{l}\text { Shannon } \\
\text { evenness }\end{array}$ & $\begin{array}{l}\text { Inverse Simpson } \\
\text { dominance }\end{array}$ & $E M F$ & $\begin{array}{c}\text { Other } \\
\text { mycorrhizal }\end{array}$ & Saprophytic & Other & Unknown \\
\hline \multicolumn{9}{|c|}{ Treatment } \\
\hline SRP & $32.3(1.35) \mathrm{b}$ & $1.26(0.12) \mathrm{b}$ & $2.14(0.26) b$ & $15.78(0.83) \mathrm{b}$ & $4.11(0.39) \mathrm{a}$ & $2.78(0.60)$ a & $6.33(0.50)$ a & $3.33(0.67) \mathrm{ab}$ \\
\hline $\mathrm{RP}$ & $32.0(1.31) \mathrm{b}$ & $1.23(0.10) b$ & $1.99(0.17) \mathrm{b}$ & $16.11(1.09) \mathrm{b}$ & $4.00(0.50) \mathrm{a}$ & $4.22(0.43) \mathrm{a}$ & $5.33(0.71)$ a & $2.33(0.41) b$ \\
\hline $\mathrm{P}$ & $34.7(2.43) \mathrm{b}$ & $1.39(0.14) b$ & $2.37(0.25) \mathrm{b}$ & $17.56(0.85) b$ & $4.44(0.53) \mathrm{a}$ & $3.44(0.84)$ a & $6.78(0.60)$ a & $2.44(0.71) b$ \\
\hline $\mathrm{F}$ & $49.1(2.62)$ a & $2.61(0.13)$ a & $9.14(1.31) \mathrm{a}$ & $30.67(2.46)$ a & $3.67(0.39)$ a & $3.89(0.48)$ a & $6.11(0.63)$ a & $4.78(0.52)$ a \\
\hline \multicolumn{9}{|l|}{ Area } \\
\hline South & $38.2(2.37) \mathrm{a}$ & $1.54(0.22) \mathrm{a}$ & $3.73(1.00) \mathrm{a}$ & $21.2(1.77) \mathrm{a}$ & $4.25(0.43) \mathrm{a}$ & $3.67(0.68) \mathrm{a}$ & $5.67(0.53) \mathrm{a}$ & $3.50(0.54) \mathrm{a}$ \\
\hline Central & $35.2(3.23) \mathrm{a}$ & $1.64(0.18) \mathrm{a}$ & $3.58(0.73)$ a & $18.7(2.42)$ a & $3.58(0.36) \mathrm{a}$ & $3.75(0.58)$ a & $6.58(0.61)$ a & $2.58(0.63) \mathrm{a}$ \\
\hline North & $37.7(2.44)$ a & $1.68(0.20) \mathrm{a}$ & $4.42(1.40) \mathrm{a}$ & $20.3(2.42) \mathrm{a}$ & $4.33(0.31) \mathrm{a}$ & $3.33(0.28)$ a & $6.17(0.46)$ a & $3.58(0.51)$ a \\
\hline
\end{tabular}

Abbreviations: EMF, ectomycorrhizal fungi; F, reference forest; OTU, operational taxonomic unit; P, patch mounding RP, patch mounding and logging residual removal; SRP, patch mounding, logging residual removal and partial stump removal.

The s.e. are presented in parentheses. In the case of treatments, each number represents mean of 9 plots, and in the case of different areas 12 plots.

Letters indicate significant differences (glmer or lmer: $z$ or $t>2.00$, respectively; $P<0.05$ ) between different treatments or areas.
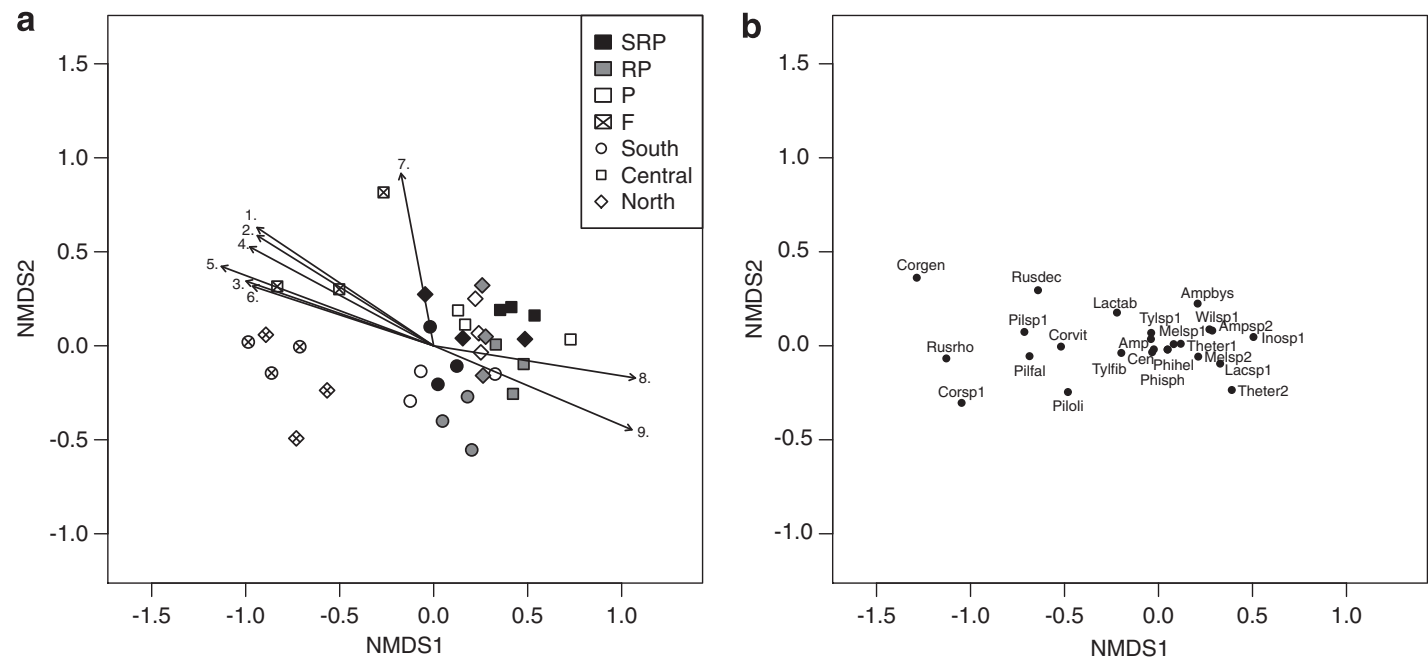

Figure 1 (a) Two-dimensional NMDS ordination (stress=0.168) using Jaccard indices of fungal OTU communities in different harvesting treatments (SRP, patch mounding, logging residual removal and partial stump removal; RP, patch mounding and logging residual removal; $\mathrm{P}$, patch mounding) and reference forest plots $(\mathrm{F})$ in South, Central and North areas. Fitted vectors $(r>0.69$ and $P<0.01)$ describing the relationship between stand characteristics, vegetation structure and fungal OTU community in the plots are presented. The length of each vector indicates the strength of correlation between the vector and the ordination configuration. Vectors (correlation, r): (1) number of OTUs (operational taxonomic units) (0.85); (2) Shannon diversity (0.83); (3) inverse Simpson dominance (0.79); (4) number of EMF OTUs (0.83); (5) coverage (\%) of mosses (0.90); (6) coverage (\%) of shrub species (0.76); (7) nitrogen content of rhizosphere soil (0.70); (8) sapling height growth in year 2011 (0.81); (9) sequence number of T. terrestris 1 (the most common OTU) in each sample (0.86). (b) Species ordination of the same plots. The 25 most common OTUs in the whole data set are shown. For abbreviations, see Table 4 . 
Table 3a Permutational multivariate ANOVA

\begin{tabular}{|c|c|c|c|c|c|c|}
\hline & $d f$ & $\begin{array}{l}\text { Sum of } \\
\text { squares }\end{array}$ & $\begin{array}{l}\text { Mean of } \\
\text { squares }\end{array}$ & F-value & $\mathrm{R}^{2}$ & $\mathrm{P}$-value \\
\hline Treatment & 2 & 0.445 & 0.223 & 1.11 & 0.078 & 0.239 \\
\hline Area & 2 & 0.881 & 0.440 & 2.19 & 0.154 & 0.001 \\
\hline Treatment $\times$ Area & 4 & 0.791 & 0.198 & 0.98 & 0.138 & 0.540 \\
\hline Residuals & 18 & 3.622 & 0.201 & & 0.631 & \\
\hline Total & 26 & 5.739 & & & 1.000 & \\
\hline
\end{tabular}

Abbreviations: ANOVA, analysis of variance; OTU, operational taxonomic unit; P, patch mounding; RP, patch mounding and logging residual removal; SRP, patch mounding, logging residual removal and partial stump removal.

Permutational multivariate ANOVA of fungal OTU community composition in root samples of Norway spruce saplings grown in different harvesting treatments (SRP, RP, P) in South, Central and North areas, tested without reference forest plots (F, compare with Table 3b). A Jaccard index analysis was chosen with 999 permutations. Bold print indicates statistically significant differences $(P<0.01)$

Table 3b Permutational multivariate ANOVA

\begin{tabular}{lrrrrrr}
\hline & $d f \begin{array}{c}\text { Sum of } \\
\text { squares }\end{array}$ & $\begin{array}{c}\text { Mean of } \\
\text { squares }\end{array}$ & & & & \\
& & & & & & \\
& 3 & 1.909 & 0.636 & 3.06 & 0.207 & $\mathbf{0 . 0 0 1}$ \\
Treatment & 2 & 0.927 & 0.463 & 2.23 & 0.100 & $\mathbf{0 . 0 0 1}$ \\
Area & 6 & 1.412 & 0.235 & 1.13 & 0.153 & 0.127 \\
Treatment x Area & 24 & 4.995 & 0.208 & & 0.540 & \\
Residuals & 35 & 9.243 & & & 1.000 & \\
Total & 35 & & & & & \\
\hline
\end{tabular}

Abbreviations: ANOVA, analysis of variance; OTU, operational taxonomic unit; P, patch mounding; RP, patch mounding and logging residual removal; SRP, patch mounding, logging residual removal and partial stump removal.

Permutational multivariate ANOVA of fungal OTU community composition in root samples of Norway spruce saplings grown in different harvesting treatments (SRP, RP, P) and reference forest plots (F) in South, Central and North areas. A Jaccard index analysis was chosen with 999 permutations. Bold print indicates statistically significant differences $(P<0.01)$.

diversity or richness of fungal OTUs between geographical areas (Table 2). No actual differences were found in fungal OTU assemblages of saplings that were grown in the two different nurseries (Joroinen: South and Central areas, Tuusniemi: North area) (Supplementary Table S5).

Frequencies of fungal functional groups were largely similar within harvesting treatments, whereas reference forest differed again. EMF taxa dominated in all plots, but they were significantly more frequent in reference forest than in harvesting treatments (Table 2). Unknown fungal OTUs were slightly more frequent in reference forest than in harvesting treatments RP and P (Table 2). In NMDS ordination, numbers of total fungal OTUs and EMF OTUs and diversity indices (Shannon $\mathrm{H}$, Inverse Simpson D) increased towards reference forest plots (Figure 1a).

The most common OTU, T. terrestris 1, represented more than half of all sequence data (53\%, Table 4). This OTU dominated fungal communities in the harvesting treatments (SRP, RP, P) with relative abundances of 69,71 and $65 \%$, respectively. Across all samples, sequences of $T$. terrestris 1 were equally distributed between harvesting treatments $(32.7,33.8$ and $30.8 \%$, respectively), whereas a significantly smaller proportion of sequences $(2.7 \%)$ occurred in reference forest (glmer: $z=54.5$, 57.8 , 55.5, respectively). In reference forests, T. terrestris 1 showed the highest abundance in the Central area (12\%) and was significantly less abundant in the South and in the North (4 and 1\%, glmer: $z=-10.25$ and 13.62 , respectively). In NMDS ordination, the number of sequences representing T. terrestris 1 increased towards harvesting treatments, when fitted as a vector (Figure 1a).

The indicator analysis revealed 12 OTUs that were good indicators for uncut reference forest (indicator value $>0.7, P<0.05$ ), Piloderma fallax, Russula rhodopus and Cortinarius vitiosus OTUs having the highest indicator values. The other indicators for reference forest were Ascomycota sp., Piloderma olivaceum, Hebeloma sp., Piloderma sp.2, Russula atrorubens, Russula consobrina, Oidiodendron sp., Piloderma sp.1 and Helotiales sp. In contrast, only a few OTUs (mainly Thelephora) were indicators for $\mathrm{P}$ treatment and $\mathrm{RP}$ treatment, and none solely for SRP treatment. The analysis highlighted seven OTUs that were indicators for all harvesting treatments. From these OTUs, three were identified as $T$. terrestris, two as Meliniomyces spp. and the remaining two as Laccaria and Inocybe. In NMDS ordination, Cortinarius or Russula species were associated with reference forest plots, whereas OTUs identified as Thelephora, Laccaria, Meliniomyces, Inocybe, Wilcoxina, Amphinema and Phialocephala spp. were associated with the harvesting treatment plots (Figure 1b).

\section{Sapling growth and soil nutrients}

Sapling height growth was generally similar in all harvesting treatments. Stump removal and logging residue removal did not cause any further changes in height growth (Figure 2). However, shoot biomass was slightly higher in the SRP treatment than in the P treatment (lmer: $t=-2.78$ ). Biomass accumulation and height growth of saplings were rather similar in different study areas (South, Central and North). In the $\mathrm{P}$ treatment, sapling height growth was higher in Central area than in North (lmer: $t=-3.12$ ), whereas shoot biomass was higher in Central area than in South or North both in RP (lmer: $t=-2.04$ and -2.61 , respectively) and SRP treatments (lmer: $t=-3.28$ and -1.99 , respectively). The saplings grown in reference forest were vigorous, although significantly smaller than in the harvesting treatments (SRP, RP, and P) measured both as height growth (lmer: $t=24.6,23.4$ and 21.9, respectively) and shoot biomass (lmer: $t=14.6,15.6$ and 15.8 , respectively). 
Table 4 Most abundant fungal taxa in the whole sequence data representing all 36 plots, based on rarefied data

\begin{tabular}{|c|c|c|c|c|c|c|c|c|c|c|}
\hline Taxon & Abbr. & Phylum & $\begin{array}{c}\text { Functional } \\
\text { role }\end{array}$ & $\begin{array}{l}\text { Reference } \\
\text { sequence }\end{array}$ & $\begin{array}{l}\text { No. of seq. } \\
\text { (from all \%) }\end{array}$ & $\begin{array}{l}\text { Seq. in } \\
\text { SRP }\end{array}$ & Seq. in $R P$ & Seq. in $P$ & Seq. in $F$ & Plots \\
\hline T. terrestris 1 & Theter1 & B & EMF & JQ711981 & 20947 (53\%) & 6858 & 7071 & 6455 & 563 & 35 \\
\hline Tylospora sp.1 & Tylsp1 & B & EMF & JQ711823 & 1705 (4\%) & 742 & 403 & 238 & 323 & 32 \\
\hline Tylospora fibrillosa & Tylfib & B & EMF & JN943897 & $1311(3 \%)$ & 80 & 182 & 296 & 753 & 24 \\
\hline Amphinema sp.1 & Ampsp1 & B & EMF & FR877518 & $1256(3 \%)$ & 236 & 326 & 545 & 150 & 27 \\
\hline Piloderma sp.1 & Pilsp1 & B & EMF & JQ616799 & $861(2 \%)$ & 64 & 2 & 188 & 606 & 11 \\
\hline P. fallax & Pilfal & B & EMF & DQ469285 & $829(2 \%)$ & 11 & 1 & 9 & 808 & 13 \\
\hline Wilcoxina sp.1 & Wilsp1 & A & EMF & FM992988 & $734(2 \%)$ & 205 & 245 & 278 & 6 & 21 \\
\hline Piloderma sphaerosporum & Pilsph & B & EMF & JQ711930 & $695(2 \%)$ & 90 & 104 & 87 & 414 & 33 \\
\hline Laccaria sp. & Lacsp1 & B & EMF & JX030274 & $664(2 \%)$ & 286 & 101 & 265 & 13 & 25 \\
\hline Cenococcum geophilum & Cengeo & A & EMF & JN943885 & $644(2 \%)$ & 68 & 137 & 36 & 402 & 32 \\
\hline Russula decolorans & Rusdec & B & EMF & AF418637 & $628(2 \%)$ & 2 & 0 & 1 & 625 & 5 \\
\hline P. olivaceum & Piloli & B & EMF & DQ469290 & $520(1 \%)$ & 14 & 1 & 46 & 459 & 12 \\
\hline R. rhodopus & Rusrho & B & EMF & UDB016071 & $510(1 \%)$ & 0 & 0 & 0 & 510 & 8 \\
\hline Amphinema sp.2 & Ampsp2 & B & EMF & JN943919 & $471(1 \%)$ & 144 & 91 & 131 & 105 & 26 \\
\hline Fungus sp. & Fungus & A & other & JF300539 & $376(1 \%)$ & 91 & 115 & 83 & 87 & 36 \\
\hline Inocybe sp.1 & Inosp1 & B & EMF & HM196017 & $370(1 \%)$ & 52 & 92 & 226 & 0 & 15 \\
\hline Cortinarius gentilis & Corgen & B & EMF & EU266692 & $333(1 \%)$ & 0 & 0 & 0 & 333 & 2 \\
\hline C. vitiosus & Corvit & B & EMF & JN114096 & $316(1 \%)$ & 8 & 1 & 16 & 292 & 14 \\
\hline T. terrestris 2 & Theter2 & B & EMF & AF272923 & $307(1 \%)$ & 18 & 142 & 147 & 0 & 16 \\
\hline Phialocephala helvetica & Phihel & A & other & AY078136 & $290(1 \%)$ & 89 & 86 & 43 & 72 & 36 \\
\hline Cortinarius sp. 1 & Corsp1 & B & $\mathrm{EMF}$ & GQ159856 & $290(1 \%)$ & 0 & 0 & 1 & 289 & 5 \\
\hline Meliniomyces sp.1. & Melsp1 & A & myсо & HM044590 & $284(1 \%)$ & 55 & 58 & 84 & 87 & 33 \\
\hline Lactarius tabidus & Lactab & B & EMF & HM189833 & $271(1 \%)$ & 14 & 32 & 12 & 213 & 12 \\
\hline Meliniomyces sp.2. & Melsp2 & A & myco & JF792512 & $270(1 \%)$ & 110 & 86 & 64 & 11 & 29 \\
\hline Amphinema byssoides & Ampbys & B & EMF & JN943932 & $232(1 \%)$ & 31 & 47 & 112 & 42 & 20 \\
\hline
\end{tabular}

Abbreviations: A, Ascomycota; B, Basidomycota; EMF, ectomycorrhizal fungi; F, reference forest; myco, other mycorrhizal fungi; myco, saprophytic or unknown; other, fungi with other functional roles than EMF, OTU, operational taxonomic unit; P, patch mounding; RP, patch mounding and logging residual removal; SRP, patch mounding, logging residual removal and partial stump removal.

Match to reference sequences $>97 \%$. Number of plots, in which occurred, is shown.

Soil organic matter, total $\mathrm{N}$ and phosphorus concentration in rhizosphere did not differ between the harvesting treatments. In the reference forest, soil organic matter and $\mathrm{N}$ were at a higher level than in the harvesting treatments (SRP, RP and P) (lmer: $t=-2.42,-3.60$ and $-4.18 ; t=-2.44,-2.52$ and -2.28 , respectively; Figure 3), whereas soil phosphorus in reference forest was at a lower level as compared with RP and SRP treatments (lmer: $t=3.16$ and 2.87, respectively). In the Central area, soil phosphorus concentration was higher than in the South or North areas (lmer: $t=-6.66$ and -4.96 , respectively), and higher in RP and SRP treatments than in the $\mathrm{P}$ treatment $(t=-3.66$ and -2.00 , respectively).

In NMDS ordination, all sapling growth variables acted in the same way; thus, only one vector for sapling growth is shown. Sapling height growth increased towards harvesting treatments (Figures 1a, $r=0.81, P<0.001)$. From soil variables, total $\mathrm{N}$ concentration increased towards the plots of the Central area (Figures 1a, $r=0.70, P<0.001$ ). Coverages of moss species and dwarf shrub species were higher in reference forests (Figures 1a, $r=0.90$ and $0.76, P<0.001$ ), as shown by vectors.

\section{Discussion}

Contrary to our expectations, neither EMF diversity nor fungal community composition of Norway spruce sapling roots differed between the studied energy wood-harvesting treatments, showing that recently adapted harvesting methods, partial stump removal or logging residue removal did not have an additional impact on fungal communities associated with spruce sapling roots as compared with the widely used patch mounding solely. Similarly, height growth of spruce saplings was equal in all harvesting treatments.

Site preparation solely and in combination with logging residue removal induces a significant release of soluble $\mathrm{N}$ from soil, and this effect may persist decades after forest regeneration (Kubin, 1998, 2012). Stump harvesting disrupts the soil more severely than conventional site preparation practices and may further increase nutrient leaching (Aherne et al., 2012) and soil compaction (PageDumroese et al., 1998; Zabowski et al., 2008). Both stump and logging residue removal have been reported to reduce long-term $\mathrm{C}$ and $\mathrm{N}$ pools, which may affect future tree generations (Palviainen et al., 2010; Strömgren et al, 2013), and EMF mycelia, which commonly inhabit decaying wood (Tedersoo et al., 2008; Rajala et al., 2011). As intense harvesting practices have a potential to profoundly change abiotic soil properties, they can be expected to also alter EMF communities. However, neither stump harvesting nor logging residue removal affected fungal community composition or diversity in roots of Norway spruce saplings compared with patch 
a
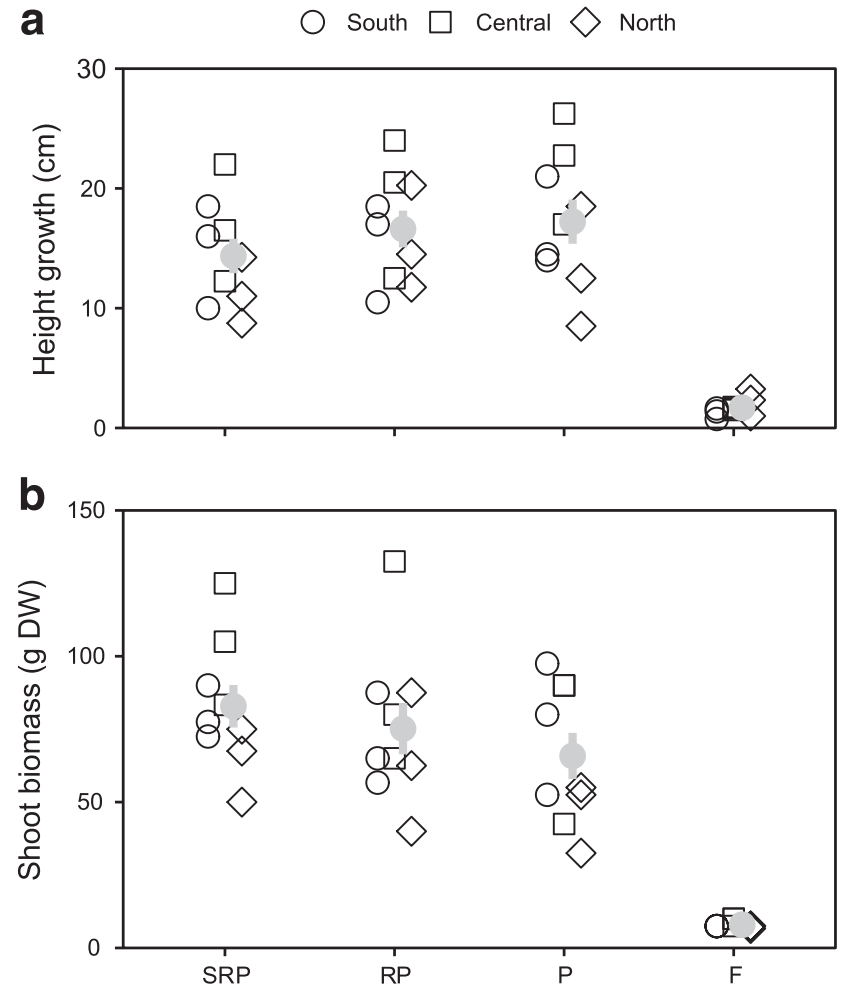

Figure 2 Sapling (a) height growth in 2011 (cm) and (b) shoot biomass (g dry weight) in different harvesting treatments (SRP, patch mounding, logging residual removal and partial stump removal; RP, patch mounding and logging residual removal; P, patch mounding) and reference forest plots (F) in South, Central and North. Average and s.e. for treatments are presented in gray color. Each area symbol stands for three to four replicates.

mounding solely. Our results are parallel with those of Kataja-aho et al. (2012), who did not detect significant changes in EMF communities of spruce saplings after three growing seasons following stump removal. This suggests that impacts of stump removal on soil and microbial communities may occur beyond the microsite where seedlings are planted. Similar to our results, logging residue removal was not found to affect fungal biomass in soil and EMF communities in roots, despite reductions in root density and organic layer (Mahmood et al., 1999; Hargerberg and Wallander, 2002). However, Walker et al. (2012) found woody debris removal to slightly affect EMF community composition in the roots of Picea engelmannii saplings.

Several factors may contribute to the lack of differences in fungal communities between the harvesting treatments. First, replacement of nursery-origin fungi by indigenous EMF occurs slowly with sapling root extension during 2-4 successive years after planting (Dahlberg and Stenström, 1991; Le Tacon et al., 1992; Pennanen et al., 2005). Colonization ability of indigenous EMF in clear cuts shows interspecific variation and may start from aerial spores, soil propagules or mycelia attached to fine roots within stumps (Jones et al., 2003). Second, patch mounding creates microsites rich in mineral a
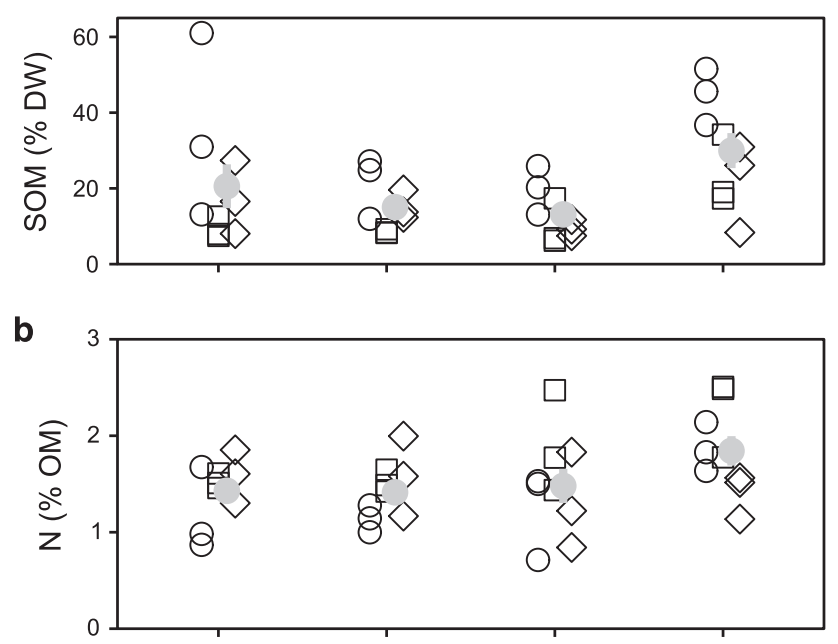

C

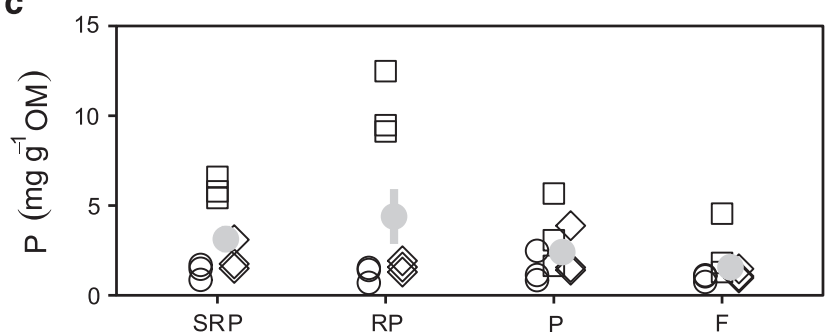

Figure 3 (a) Organic matter (OM; \% dry weight) and (b) total nitrogen $(\mathrm{N})(\% \mathrm{OM})$, and $(\mathbf{c})$ total phosphorus $(\mathrm{P})$ concentrations $\left(\mathrm{mg} \mathrm{g}^{-1} \mathrm{OM}\right)$ in the sampled patches taken from different harvesting treatments (SRP, patch mounding, logging residual removal and partial stump removal; RP, patch mounding and logging residual removal; $\mathrm{P}$, patch mounding) and reference forest plots (F) in South, Central and North areas. Average and s.e. for treatments are presented in gray color. Each area symbol stands for three to four replicates.

soil and quite isolated from organic soil and its fungal inoculum (Jones et al., 2002; Pennanen et al., 2005). Thus, patch mounding may be the major unifying factor in our root EMF communities regardless of the harvesting treatment. Furthermore, nursery fungi already colonizing roots of planted seedlings may have a competitive advantage over indigenous EMF in colonizing newly forming roots (Parladé et al., 1999). Root EMF in our harvesting treatments may originate either from nurseries or from local EMF inoculum; nevertheless, both sources may contain similar EMF species. T. terrestris was reported as being among the first fungi to colonize non-EMF seedlings at clear-cut sites, likely due to its efficient proliferation from spores (Walker and Jones, 2013). In our data, T. terrestris 1 was the dominant OTU in the harvesting treatments, whereas $<3 \%$ of this OTU's sequences occurred in reference forests. Abundance of T. terrestris in harvesting treatments was almost as high as the root colonization rate of this species in seedlings grown in the same nursery (Kataja-aho et al., 2012), which provided seedling material for South and Central areas in the present study. 
However, after three growing seasons no effect on fungal OTU assemblages was found that could be attributed to the two different nurseries (Joroinen for the South and Central areas and Tuusniemi for the North area). This may indicate that both nurseries shared a common pool of fungal taxa, while it seems that sapling roots were colonized also by each area's own species pool.

In the reference forests with intact organic layer, EMF communities of sapling roots were significantly more diverse and even, consisting of typical coniferous forest symbiont species, such as Piloderma, Cortinarius and Russula (Hansen and Knudsen, 1992), which are suggested to mobilize organically bound nutrients from soil humus (Buée et al., 2007; Bödeker et al., 2014; Velmala et al., 2014). In the intact forest soil, trees and saplings are typically connected by a shared EMF mycelial network (Simard et al., 2012). Mycelial extension from mature trees is also likely responsible for more diverse EMF community in our planted seedlings in the reference forest, despite uncertainty about whether shared EMF connections with other trees have been formed.

Sensitivity of forest sites to energy wood harvesting and, to the most intense practice, stump removal is determined by many site-related factors, including microclimate, mineral soil texture, organic $\mathrm{C}$ content and soil nutrient availability (Thiffault et al., 2011). Total nitrogen and phosphorus in sapling rhizosphere and sapling growth varied slightly between geographical areas in the present study, whereas overall effects of harvesting treatments on nutrients and sapling height growth were similar. We detected only slightly increased shoot biomass in the treatment, including stump and logging residue removal (SRP) compared with patch mounding. Previous studies show that stump removal may increase growth of Norway spruce seedlings and suggest increased availability of soluble nutrients in soil (Menkis et al., 2010) or high EMF colonization received from nursery (Kataja-aho et al., 2012) to be plausible reasons. However, slight differences in tree sapling growth may become even less apparent in the long term, as has been observed during 10 (Hope, 2007) and 30 years (Karlsson and Tamminen, 2013) of monitoring. Thus, stump or logging residue removal may have only minor or temporary effects on stand productivity.

Stump harvesting is a rather new forestry practice and its impact on soil microbiota has not been extensively studied. The present study offers the most thorough insight into root EMF communities after energy wood harvesting. Despite that no evidence was found that stump removal would additively reduce EMF diversity or spruce sapling growth compared with patch mounding alone or with logging residual removal, our results have to be interpreted with caution. Stump removal is an intensive forestry practice changing soil biological and physico-chemical properties, which may lead to long-term effects on composition and functioning of microbial communities essential in soil carbon and nutrient cycling. Our 3-year study is still relatively short in the context of forest regeneration and, therefore, we urge the need for long-term studies on energy wood-harvesting practices.

\section{Conflict of Interest}

The authors declare no conflict of interest.

\section{Acknowledgements}

We thank the personnel of the Finnish Forest Research Institute, Heini Koivuniemi, Marko Suokas (BioSer Oulu), Mysore Tejesvi and Sami Aikio for their help with analyses and in field work. Aaron Bergdahl is acknowledged for language revision. We thank the land owner UPM Kymmene. This study was funded by The Ella and Georg Ehrnrooth Foundation, Niemi Foundation, Biological Interactions (BIOINT) Graduate School, Faculty of Science (University of Oulu) and Academy of Finland project \#138309.

\section{References}

Abarenkov K, Nilsson RH, Larsson K-H, Alexander IJ, Eberhardt U, Erland S et al. (2010). The UNITE database for molecular identification of fungi - recent updates and future perspectives. N Phytol 186: 281-285.

Agerer R. (2001). Exploration types of ectomycorrhizae. A proposal to classify ectomycorrhizal mycelial systems according to their patterns of differentiation and putative ecological importance. Mycorrhiza 11: 107-114.

Aherne J, Posch M, Forsius M, Lehtonen A, Härkönen K. (2012). Impacts of forest biomass removal on soil nutrient status under climate change: a catchmentbased modelling study for Finland. Biogeochemistry 107: 471-488.

Ahti T, Hämet-Ahti L, Jalas J. (1968). Vegetation zones and their sections in northwestern Europe. Ann Bot Fenn 5: 169-211.

Allmér J, Stenlid J, Dahlberg A. (2009). Logging-residue extraction does not reduce the diversity of litter-layer saprotrophic fungi in three Swedish coniferous stands after 25 years. Can J Forest Res 39: 1737-1748.

Amend AS, Seifert KA, Bruns TD. (2010). Quantifying microbial communities with 454 pyrosequencing: does read abundance count? Mol Ecol 19: 5555-5565.

Bates D, Maechler M, Bolker B. (2011). lme4: Linear mixed-effects models using S4 classes. R package version 0.999375-42. http://CRAN.R-projects. org/package=lme4.

Björheden R. (2006). Drivers behind the development of forest energy in Sweden. Biomass Bioenerg 30: 289-295.

Buée M, Courty PE, Mignot D, Garbaye J. (2007). Soil niche effect on species diversity and catabolic activities in an ectomycorrhizal community. Soil Biol Biochem 39: 1947-1955. 
Bödeker ITM, Clemmensen KE, de Boer W, Martin F, Olson A, Lindahl BD. (2014). Ectomycorrhizal Cortinarius species participate in enzymatic oxidation of humus in northern forest ecosystems. N Phytol 203: $245-256$

Caporaso JG, Kuczynski J, Stombaugh J, Bittinger K, Bushman FD, Costello EK et al. (2010). QIIME allows analysis of high-throughput community sequencing data. Nat Methods 7: 335-336.

Clemmensen KE, Bahr A, Ovaskainen O, Dahlberg A, Ekblad A, Wallander $\mathrm{H}$ et al. (2013). Roots and associated fungi drive long-term carbon sequestration in boreal forest. Science 339: 1615-1618.

Crawley MJ. (2007). The $R$ Book. Wiley and Sons: Chichester, UK.

Dahlberg A, Stenström E. (1991). Dynamic changes in nursery and indigenous mycorrhiza of Pinus sylverstris seedling planted out in forest and clearcuts. Plant Soil 136: 73-86.

De Cáceres M, Legendre P. (2009). Associations between species and groups of sites: indices and statistical inference. Ecology 90: 3566-3574.

Díaz-Yáñez O, Mola-Yedoga B, Anttila P, Röser D, Asikainen A. (2013). Forest chips for energy in Europe: current procurement methods and potentials. Renew Sust Energ Rev 21: 562-571.

Edgar RC. (2010). Search and clustering orders of magnitude faster than BLAST. Bioinformatics 26: 2460-2461.

EU (2009). Directive 2009/28/EC of the European Parliament and of the Council of 23 April 2009 on the promotion of the use of energy from renewable sources and amending and subsequently repealing Directives 2001/77EC and 2003/30/EC. Off J Eur Union L140: $16-65$.

Flykt E, Timonen S, Pennanen T. (2008). Variation of ectomycorrhizal colonization of spruce seedlings in Finnish forest nurseries. Silva Fenn 42: 571-585.

Godbold DL, Hoosbeek MR, Lukac M, Cotrufo MF, Janssens IA, Ceulemans R et al. (2006). Mycorrhizal hyphal turnover as a dominant process for carbon input into soil organic matter. Plant Soil 281: 15-24.

Hagerman SM, Jones MD, Bradfield GE, Gillespie M, Durall DM. (1999). Effects of clear-cut logging on the diversity and persistence of ectomycorrhizae at a subalpine forest. Can J Forest Res 29: 124-134.

Hansen L, Knudsen H. (1992). Nordic Macromycetes, Vol. 2. Polyporales, Boletales, Agaricales, Russulales. Nordsvamp: Copenhagen.

Hargerberg D, Wallander H. (2002). The impact of forest residue removal and wood ash amendment on the growth of the ectomycorrhizal external mycelium. FEMS Microbiol Ecol 39: 139-146.

Heinonsalo J, Koskiahde I, Sen R. (2007). Scots pine bait seedling performance and root colonizing ectomycorrhizal fungal community dynamics before and during the 4 years after forest clear-cut logging. Can J Forest Res 37: 415-429.

Heinonsalo J, Sen R. (2007). Scots pine ectomycorrhizal fungal inoculum potential and dynamics in podzolspecific humus, eluvial and illuvial horizons one and four growth seasons after forest clear-cut logging. Can J Forest Res 37: 404-414.

Hope GD. (2007). Changes in soil properties, tree growth, and nutrition over a period of 10 years after stump removal and scarification on moderately coarse soils in interior British Columbia. Forest Ecol Manag 242: 625-635.

Hunt GA. (1992). Effects of mycorrhizal fungi on quality of nursery stock and plantation performance in the southern interior of British Columbia. Final Report. B.C. FRDA Project No. F52-41-006. Canada-B.C. FRDA, Canadian Forest Service: Victoria.

Jones MD, Durall DM, Cairney JWG. (2003). Ectomycorrhizal fungal communities in young forest stands regenerating after clearcut logging. $N$ Phytol 157: $399-422$.

Jones MD, Hagerman SM, Gillespie M. (2002). Ectomycorrhizal colonization and richness of previously colonized, containerized Picea engelmannii does not vary across clearcuts when planted in mechanically site-prepared mounds. Can J For Res 32: 1425-1433.

Jonsson LM, Nilsson M-C, Wardle DA, Zackrisson O. (2001). Context dependent effects of ectomycorrhizal species richness on tree seedlings productivity. Oikos 93: 353-364.

Kataja-aho S, Pennanen T, Lensu A, Haimi J. (2012). Does stump removal affect early growth and mycorrhizal infection of spruce (Picea abies) seedlings in clearcuts? Scand J Forest Res 27: 746-753.

Karlsson K, Tamminen P. (2013). Long-term effects of stump harvesting on soil properties and tree growth in Scots pine and Norway spruce stands. Scand J Forest Res 28: 550-558.

Kernaghan G, Sigler L, Khasa D. (2003). Mycorrhizal and root endophytic fungi of containerized Picea glauca seedlings assessed by rDNA sequence analysis. Microbial Ecol 45: 128-136.

Korkama T, Pakkanen A, Pennanen T. (2006). Ectomycorrhizal community structure varies among Norway spruce (Picea abies ) clones. N Phytol 171: 815-824.

Kubin E. (1998). Leaching of nitrate nitrogen into the groundwater after clear felling and site preparation. Boreal Environ Res 3: 3-8.

Kubin E. (2012). Long-term effects of silvicultural practices on groundwater quality in boreal forest environment. In: Krecek J, Haigh M, Hofer T, Kubin E (eds) Management of Mountain Watersheds. Springer Capital Publishing Company: New Delhi, pp 192-199.

Le Tacon F, Alvarez IF, Bouchard D, Henrion B, Jackson RM, Luff S et al. (1992). Variations in field response of forest trees to nursery ectomycorrhizal inoculation in Europe. In Read DJ, Lewis DH, Fitter AH, Alexander IJ (eds) Mycorrhizas in Ecosystems. CAB International: Wallingford, pp 119-134.

Lindahl BD, Ihrmark K, Boberg J, Trumbore SE, Högberg P, Stenlid J et al. (2007). Spatial separation of litter decomposition and mycorrhizal nitrogen uptake in a boreal forest. N Phytol 173: 611-620.

Mahmood S, Finlay RD, Erland S. (1999). Effects of repeated harvesting of forest residues on the ectomycorrhizal community in a Swedish spruce forest. N Phytol 142: 577-585.

Margulies M, Egholm M, Altman WE, Attiya S, Bader JS, Bemben LA et al. (2005). Genome sequencing in microfabricated high-density picolitre reactors. Nature 437: 376-38.

Martin KJ, Rygiewicz PT. (2005). Fungal-specific PCR primers developed for analysis of the ITS region of environmental DNA extracts. BMC Microbiol 5: 28. 
Menkis A, Uotila A, Arhipova N, Vasaitis R. (2010). Effects of stump and slash removal on growth and mycorrhization of Picea abies seedlings outplanted on a forest clear-cut. Mycorrhiza 20: 505-509.

Oksanen J, Blanchet FG, Kindt R, Legendre P, Minchin PR, O'Hara RB et al. (2013). vegan: Community Ecology Package. R Package Version 2.0-6. http://CRAN. R-project.org/package=vegan.

Page-Dumroese DS, Harvey AE, Jurgensen MF, Amaranthus MP. (1998). Impacts of soil compaction and tree stump removal on soil properties and outplanted seedlings in northern Idaho, USA. Can J Soil Sci 78: 29-34.

Palviainen M, Finér L, Laiho R, Shorohova E, Kapitsa E, Vanha-Majamaa I. (2010). Carbon and nitrogen release from decomposing Scots pine, Norway spruce and silver birch stumps. Forest Ecol Manag 259: 390-398.

Parladé J, Alvarez IF, Pera J. (1999). Coinoculation of containerized Douglas-fir (Pseudotsuga menziesii) and maritime pine (Pinus pinaster) seedlings with the ectomycorrhizal fungi Laccaria bicolor and Rhizopogon spp. Mycorrhiza 8: 189-195.

Pennanen T, Heiskanen J, Korkama U. (2005). Dynamics of ectomycorrhizal fungi and growth of Norway spruce seedling after planting on a mounded forest clearcut. Forest Ecol Manag 213: 243-252.

$\mathrm{R}$ Development Core Team (2013). R: A language and environment for statistical computing. R Foundation for Statistical Computing: Vienna, Austria. http:// www.R-project.org.

Rajala T, Peltoniemi M, Hantula J, Mäkipää R, Pennanen T. (2011). RNA reveals a succession of active fungi during the decay of Norway spruce logs. Fungal Ecol 4: 437-444.

Read DJ, Perez-Moreno J. (2003). Mycorrhizas and nutrient cycling in ecosystemns - a journey towards relevance? N Phytol 157: 475-492.

Reeder J, Knight R. (2010). Rapidly denoising pyrosequencing amplicon reads by exploiting rank-abundance distributions. Nat Methods 7: 668-669.

Rinaldi AC, Comandini O, Kuyper TW. (2008). Ectomycorrhizal fungal diversity: separating the wheat from the chaff. Fungal Divers 33: 1-45.

Saravesi K, Markkola A, Rautio P, Tuomi J. (2011). Simulated mammal browsing and host gender effects on dual mycorrhizal Salix repens. Botany 89: 35-42.

Simard SW, Beiler KJ, Bingham MA, Deslippe JR, Philip LJ, Teste FR. (2012). Mycorrhizal networks: Mechanisms, ecology and modelling. Fungal Biol Rev 26: $39-60$.

Smith SE, Read DJ. (2008). Mycorrhizal Symbiosis. Academic Press: London.
Soil Survey Staff (1999). Soil taxonomy: a basic system of soil classification for making and interpreting soil surveys. Natural Resources Conservation Service. US Department of Agriculture: Washington, DC.

Strömgren M, Gustaf E, Olsson BA. (2013). Carbon stocks in four forest stands in Sweden 25 years after harvesting of slash and stumps. Forest Ecol Manag 290: 59-66.

Tedersoo L, May TW, Smith ME. (2010). Ectomycorrhizal lifestyle in fungi: global diversity, distribution, and evolution of phylogenetic lineages. Mycorrhiza 20: 217-263.

Tedersoo L, Suvi T, Jairus T, Kõljalg U. (2008). Forest microsite effects on community composition of ectomycorrhizal fungi on seedlings of Picea abies and Betula pendula. Environ Microbiol 10: 1189-1201.

Thiffault E, Hannam KD, Paré D, Titus BD, Hazlett PW, Maynard DG et al. (2011). Effects of forest biomass harvesting on soil productivity in boreal and temperate forests - A review. Environ Rev 19: 278-309.

Walker JKM, Jones MD. (2013). Little evidence for niche partitioning among ectomycorrhizal fungi on spruce seedlings planted in decayed wood versus mineral soil microsites. Oecologia 173: 1499-1511.

Walker JKM, Ward V, Paterson C, Jones MD. (2012). Coarse woody debris retention in subalpine clearcuts affects ectomycorrhizal root tip community structure within fifteen years of harvest. Appl Soil Ecol 60: 5-15.

Walmsley JD, Godbold DL. (2010). Stump harvesting for bioenergy - A review of the environmental impacts. Forestry 83: 17-38.

Velmala SM, Rajala T, Heinonsalo J, Taylor AFS, Pennanen T. (2014). Profiling functions of ectomycorrhizal diversity and root structuring in seedlings of Norway spruce (Picea abies) with fast- and slow-growing phenotypes. N Phytol 201: 610-622.

Venäläinen A, Tuomenvirta H, Pirinen P, Drebs A. (2005). A basic Finnish climate data set 1961-2000 - Description and illustrations. Reports No. 2005: 5. Finnish Meteorological Institute: Helsinki.

White TJ, Bruns T, Lee S, Taylor JW. (1990). Amplification and direct sequencing of fungal ribosomal RNA genes for phylogenetics. In: Innis MA, Gelfand DH, Sninsky JJ, White TJ (eds) PCR Protocols: A Guide to Methods and Applications. Academic Press: New York, pp 315-322.

Zabowski D, Chambreau D, Rotramel N, Thies WG. (2008). Long-term effects of stump removal to control root rot on forest soil bulk density, soil carbon and nitrogen content. Forest Ecol Manag 55: 720-727.

Supplementary Information accompanies this paper on The ISME Journal website (http://www.nature.com/ismej) 